\title{
Deoxidation Equilibrium of Aluminum and Silicon in the Liquid Iron-Nickel Alloys
}

\author{
V. Ya. DASHEVSKII, N. N. MAKAROVA, K. V. GRIGOROVITCH, A. G. KANEVSKII and V. I. KASHIN \\ Baikov Institute of Metallurgy and Materials Science, Russian Academy of Sciences, Leninskii prosp., 49, Moscow-119991, \\ Russia.
}

(Received on June 10, 2004; accepted in final form in October 7, 2004)

\begin{abstract}
Thermodynamic analysis and experiments showed the deoxidation ability of aluminum in the iron-nickel melts to be lower than that in pure iron and nickel. With an increase in the nickel content, the deoxidation ability of aluminum decreases to about $50 \% \mathrm{Ni}$ and then it rises. In pure nickel, the deoxidation ability of aluminum is almost equal to that in pure iron. On one hand, this can be explained by an increase in the bond strength of aluminum with this melt when the nickel content rises $\left(\gamma_{\mathrm{Al}(\mathrm{Fe})}^{\circ}=0.049, \gamma_{\mathrm{Al}(\mathrm{Ni})}^{\circ}=0.00022\right)$ and, on the other hand, by a decrease in that of oxygen $\left(\gamma_{\mathrm{O}(\mathrm{Fe})}^{\circ}=0.0105, \gamma_{\mathrm{O}(\mathrm{Ni})}^{\circ}=0.357\right)$. Curves of the oxygen solubility pass through the minimum whose location is independent of the nickel content in melt. The minimum oxygen concentrations are reached at $\sim 0.2 \%$ Al; the further additions of aluminum result in a rise in the oxygen concentration. Experimental and calculated results are in good agreement.

Complex deoxidation of $\mathrm{Fe}-40 \% \mathrm{Ni}$ with aluminum and silicon has been experimentally studied. The formation of solutions and chemical compounds between oxides of these elements promotes the participation of silicon in the deoxidation. The lower oxygen concentrations are reached after the combined deoxidation in comparison with the aluminum deoxidation. However, when the aluminum content rises in the melt at the same silicon concentration, this difference decreases; at a certain aluminum concentration, its deoxidation power becomes equal to that of complex action of aluminum and silicon. This occurs due to an increase in the content of aluminum oxide in slag. When the slag is saturated with aluminum oxide $\left(a_{\mathrm{Al}_{2} \mathrm{O}_{3}}=1\right)$, silicon does not take part in the deoxidation.
\end{abstract}

KEY WORDS: deoxidation equilibrium; aluminum; silicon; iron-nickel melts; thermodynamic analysis; experimental study.

\section{Introduction}

The Fe-Ni alloys are widely used for the production of modern equipment. In making these alloys, manganese, silicon, and aluminum are most often employed as deoxidizers. The deoxidation of $\mathrm{Fe}-\mathrm{Ni}$ alloys with manganese and silicon used both separately and jointly was considered earlier. ${ }^{1)}$ The thermodynamics of oxygen solutions in the iron melts alloyed with aluminum was studied in sufficient detail $^{2-5)}$ but that in nickel and Fe-Ni alloys was less profoundly investigated. ${ }^{6,7)}$

This paper represents a thermodynamic analysis of oxygen solutions in the $\mathrm{Fe}-\mathrm{Ni}$ melts deoxidized with aluminum and also the experimental data on the above deoxidation of the $\mathrm{Fe}-40 \% \mathrm{Ni}$ alloy.

Depending on the aluminum concentration in the melt, the oxides $\mathrm{FeO} \cdot \mathrm{Al}_{2} \mathrm{O}_{3}, \mathrm{NiO} \cdot \mathrm{Al}_{2} \mathrm{O}_{3}$, and $\mathrm{Al}_{2} \mathrm{O}_{3}$ can be produced as products of deoxidation of iron-nickel alloys with aluminum. For $1873 \mathrm{~K}$, at aluminum contents of higher than $5.33 \cdot 10^{-4} \%$ for iron and at those of above $3.94 \cdot 10^{-6} \%$ for nickel, the deoxidation product is $\mathrm{Al}_{2} \mathrm{O}_{3}$ only. ${ }^{8)}$ It can be assumed that, in the iron-nickel melts at $1873 \mathrm{~K}$, at aluminum contents of above $5 \cdot 10^{-4} \%$, the $\mathrm{Al}_{2} \mathrm{O}_{3}$ oxide is also the only product of reaction $\left(a_{\mathrm{Al}_{2} \mathrm{O}_{3}}=1\right)$.

\section{Thermodynamic Consideration}

Interaction of aluminum with oxygen in the iron-nickel melt

$$
\begin{aligned}
& \mathrm{Al}_{2} \mathrm{O}_{3}(\mathrm{~s})=2[\mathrm{Al}]+3[\mathrm{O}] \ldots \ldots \ldots \ldots \ldots \ldots \ldots \ldots \\
& K_{\mathrm{Al}}=\frac{\left([\% \mathrm{Al}] \cdot f_{\mathrm{Al}}\right)^{2}\left([\% \mathrm{O}] \cdot f_{\mathrm{O}}\right)^{3}}{a_{\mathrm{Al}_{2} \mathrm{O}_{3}}}
\end{aligned}
$$

where $f_{i}$ is the coefficient of activity, can be described as the sum of the reactions

$$
\begin{aligned}
& \mathrm{Al}_{2} \mathrm{O}_{3}(\mathrm{~s})=2 \mathrm{Al}(\mathrm{l})+\frac{3}{2} \mathrm{O}_{2}(\mathrm{~g}) \\
& \Delta G_{(2)}^{\circ}=1687908-325.15 T, \quad \mathrm{~J} / \mathrm{mol}^{2)} \\
& \mathrm{Al}(\mathrm{l})=[\mathrm{Al}]_{1 \%(\mathrm{Fe}-\mathrm{Ni})} \\
& \Delta G_{(3)}^{\circ}=R T \ln \left(\gamma_{\mathrm{Al}(\mathrm{Fe}-\mathrm{Ni})}^{\circ} M_{\mathrm{Fe}-\mathrm{Ni}} / M_{\mathrm{Al}} \cdot 100\right) \\
& \frac{1}{2} \mathrm{O}_{2}(\mathrm{~g})=[\mathrm{O}]_{1 \%(\mathrm{Fe}-\mathrm{Ni})} \\
& \Delta G_{(4)}^{\circ}=R T \ln \left(\gamma_{\mathrm{O}(\mathrm{Fe}-\mathrm{Ni})}^{\circ} M_{\mathrm{Fe}-\mathrm{Ni}} / M_{\mathrm{O}} \cdot 100\right)
\end{aligned}
$$

where $\gamma_{i}^{\circ}$ is the activity coefficient at infinite dilution and 
Table 1. Equilibrium constants of reaction (1), coefficients of activity, and interaction parameters for the Fe-Ni melts at $1873 \mathrm{~K}$.

\begin{tabular}{|c|c|c|c|c|c|c|}
\hline \multirow{2}{*}{$\begin{array}{c}\text { Parame- } \\
\text { ter }\end{array}$} & \multicolumn{6}{|c|}{$\mathrm{Ni} \%$} \\
\cline { 2 - 7 } & 0 & 25 & 40 & 50 & 75 & 100 \\
\hline $\log K_{\mathrm{Al}}$ & -13.699 & -12.344 & -11.976 & -11.907 & -12.375 & -13.707 \\
\hline$\gamma_{\mathrm{O}}^{\circ}$ & $0.0105^{9)}$ & 0.0168 & 0.0254 & 0.0355 & 0.0984 & $0.357^{9)}$ \\
\hline$\gamma_{\mathrm{Al}}^{\circ}$ & $0.049^{3)}$ & 0.00615 & 0.00210 & 0.00112 & 0.00035 & $0.00022^{6)}$ \\
\hline$e_{\mathrm{O}}^{\mathrm{O}}$ & $-0.17^{3)}$ & -0.132 & -0.110 & -0.092 & -0.052 & $0^{11)}$ \\
\hline$e_{\mathrm{Al}}^{\mathrm{Al}}$ & $0.043^{3)}$ & 0.0528 & 0.0589 & 0.0630 & 0.0737 & $0.0850^{6)}$ \\
\hline$e_{\mathrm{O}}^{\mathrm{Al}}$ & $-1.170^{3)}$ & -1.231 & -1.275 & -1.304 & -1.380 & $-1.470^{6)}$ \\
\hline$e_{\mathrm{Al}}^{\mathrm{O}}$ & $-1.980^{3)}$ & -2.083 & -2.151 & -2.207 & -2.335 & $-2.488^{6)}$ \\
\hline
\end{tabular}

$M_{i}$ is the molecular mass.

Determining the Gibbs energy of reaction (1) for various nickel contents in the form

$$
\Delta G_{(1)}^{\circ}=\Delta G_{(2)}^{\circ}+2 \Delta G_{(3)}^{\circ}+3 \Delta G_{(4)}^{\circ}
$$

one can calculate the equilibrium constant of reaction (1) by the formula

$$
\ln K_{\mathrm{Al}}=-\Delta G_{(1)}^{\circ} / R T
$$

The molecular mass of $\mathrm{Fe}-\mathrm{Ni}$ melts was estimated as

$$
M_{\mathrm{Fe}-\mathrm{Ni}}=M_{\mathrm{Fe}} X_{\mathrm{Fe}}+M_{\mathrm{Ni}} X_{\mathrm{Ni}}
$$

and the activity coefficients $\gamma_{\mathrm{Al}(\mathrm{Fe}-\mathrm{Ni})}^{\circ}$ and $\gamma_{\mathrm{O}(\mathrm{Fe}-\mathrm{Ni})}^{\circ}$ were calculated by the following equation ${ }^{9}$ :

$$
\begin{aligned}
& \ln \gamma_{i(\mathrm{Fe}-\mathrm{Ni})}^{\circ}=X_{\mathrm{Fe}} \ln \gamma_{i(\mathrm{Fe})}^{\circ}+X_{\mathrm{Ni}} \ln \gamma_{i(\mathrm{Ni})}^{\circ} \\
& +X_{\mathrm{Fe}} X_{\mathrm{Ni}}\left[X_{\mathrm{Ni}}\left(\ln \gamma_{i(\mathrm{Ni})}^{\circ}-\ln \gamma_{i(\mathrm{Fe})}^{\circ}+\varepsilon_{i(\mathrm{Ni})}^{\mathrm{Fe}}\right)\right. \\
& +X_{\mathrm{Fe}}\left(\ln \gamma_{i(\mathrm{Fe})}^{\circ}-\ln \gamma_{i(\mathrm{Ni})}^{\circ}+\varepsilon_{i(\mathrm{Fe})}^{\mathrm{Ni}}\right)
\end{aligned}
$$

where $X_{i}$ is the mole fraction; $\varepsilon_{i}^{j}$ is the interaction parameter when the component concentrations are expressed as mole fractions. The $\gamma_{i}^{\circ}$ activity coefficients for iron, nickel, and the iron-nickel alloys are given in Table 1. For our calculations, the following interaction parameters were used: $\varepsilon_{\mathrm{Al}(\mathrm{Fe})}^{\mathrm{Ni}}=-9.143^{7)} ; \varepsilon_{\mathrm{Al}(\mathrm{Ni})}^{\mathrm{Fe}}=-0.147^{7)} ; \varepsilon_{\mathrm{O}(\mathrm{Fe})}^{\mathrm{Ni}}=0.270^{10)}$; $\varepsilon_{\mathrm{O}(\mathrm{Ni})}^{\mathrm{Fe}}=-5.175 .{ }^{10)}$

The equilibrium constants of reaction (1) for various nickel concentrations in the melt at $1873 \mathrm{~K}$ are given in Table 1. The values obtained for iron and nickel are in good agreement with the published data, i.e., $\log K_{\mathrm{Al}(\mathrm{Fe})}=$ $-13.600^{3)} ; \log K_{\mathrm{Al}(\mathrm{Ni})}=-13.690 .{ }^{6)}$

Figure 1 shows the equilibrium constant calculated for reaction (1) depending on the content of nickel at $1873 \mathrm{~K}$, which are compared with the data on the deoxidation of iron-nickel melts with manganese and silicon. ${ }^{1)}$ The equilibrium constants are given for the interaction of deoxidizing agent with one oxygen atom dissolved in the melt, which allows us to more clearly compare the dependences for $\mathrm{Mn}, \mathrm{Si}$ and $\mathrm{Al}$. As is seen from these data, in the cases of manganese and silicon, the equilibrium constant of deoxidation decreases with the increase in the nickel concentration, which indicates that their deoxidation ability rises. In the case of aluminum, this dependence has another character, i.e., the equilibrium constant rises initially with the increase in the nickel content to about $50 \%$, and, then, it decreases. In this case, on one hand, another character of the above dependence can be explained by an increase in the

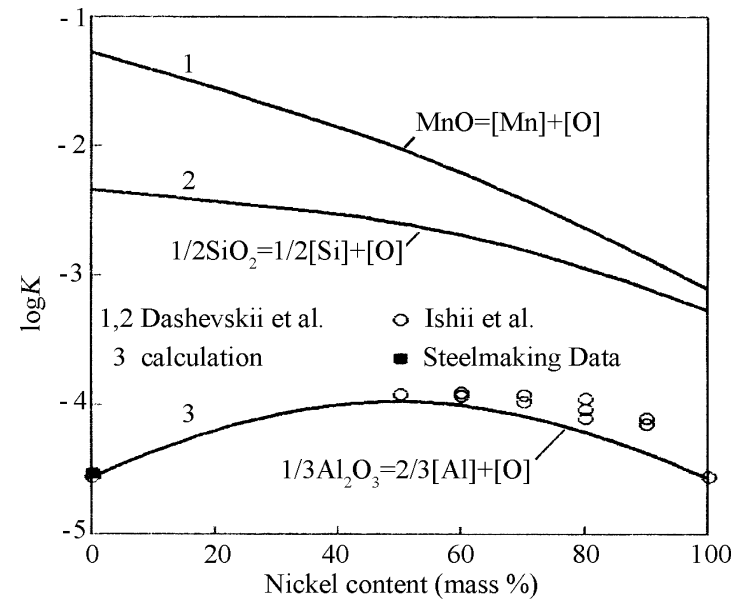

Fig. 1. Dependence of the equilibrium constant of deoxidation of $\mathrm{Fe}-\mathrm{Ni}$ melts with $\mathrm{Mn}, \mathrm{Si}$ and $\mathrm{Al}$ on Ni content at $1873 \mathrm{~K}$.

bond strength of aluminum in the melt with the rise in the nickel content $\left(\gamma_{\mathrm{Al}(\mathrm{Fe})}^{\circ}=0.049, \gamma_{\mathrm{Al}(\mathrm{Ni})}^{\circ}=0.00022\right)$ and, on the other hand, by the weakening of the oxygen bond strengths $\left(\gamma_{\mathrm{O}(\mathrm{Fe})}^{\circ}=0.0105, \gamma_{\mathrm{O}(\mathrm{Ni})}^{\circ}=0.375\right)$. The calculated results (Fig. 1) are in good agreement with the published data. ${ }^{3,6)}$

The oxygen concentration in the melt, which is in equilibrium with the specified aluminum content, can be calculated by the following equation:

$$
\begin{aligned}
\log [\% \mathrm{O}]_{\mathrm{Al}}= & \frac{1}{3}\left\{\log K_{\mathrm{Al}}+\log a_{\mathrm{Al}_{2} \mathrm{O}_{3}}-2 \log [\% \mathrm{Al}]\right. \\
& -\left[2 e_{\mathrm{Al}(\mathrm{Fe}-\mathrm{Ni})}^{\mathrm{Al}}+3 e_{\mathrm{O}(\mathrm{Fe}-\mathrm{Ni})}^{\mathrm{Al}}\right][\% \mathrm{Al}] \\
& \left.-\left[3 e_{\mathrm{O}(\mathrm{Fe}-\mathrm{Ni})}^{\mathrm{O}}+2 e_{\mathrm{O}(\mathrm{Fe}-\mathrm{Ni})}^{\mathrm{O}}\right][\% \mathrm{O}]_{\mathrm{Al}}\right\} \ldots \ldots . .
\end{aligned}
$$

where $\varepsilon_{i}^{j}$ are the interaction parameters for the cases when the component concentrations are expressed as mass percents.

In the right-hand part of Eq. (9), $\left(K_{\mathrm{Al}} /[\% \mathrm{Al}]^{2} f_{\mathrm{Al}}^{2} f_{\mathrm{O}}^{3}\right)^{1 / 3}$ may substitute for $[\% \mathrm{O}]_{\mathrm{Al}}$. Since $[\% \mathrm{O}]_{\mathrm{Al}}$ is very small, one can assume ${ }^{1,2)}$ that $\left(K_{\mathrm{Al}} /[\% \mathrm{Al}]^{2} f_{\mathrm{Al}}^{2} f_{\mathrm{O}}^{3}\right)^{1 / 3} \approx\left(K_{\mathrm{Al}} /[\% \mathrm{Al}]^{2}\right)^{1 / 3}$. This assumption does not appreciably affect the calculation of $[\% \mathrm{O}]_{\mathrm{Al}}$. Then Eq. (9) takes the form

$$
\begin{aligned}
\log [\% \mathrm{O}]_{\mathrm{Al}}= & \frac{1}{3}\left\{\log K_{\mathrm{Al}}-2 \log [\% \mathrm{Al}]\right. \\
& -\left[2 e_{\mathrm{Al}(\mathrm{Fe}-\mathrm{Ni})}^{\mathrm{Al}}+3 e_{\mathrm{O}(\mathrm{Fe}-\mathrm{Ni})}^{\mathrm{Al}}\right][\% \mathrm{Al}] \\
& \left.-\left[3 e_{\mathrm{O}(\mathrm{Fe}-\mathrm{Ni})}^{\mathrm{O}}+2 e_{\mathrm{Al}(\mathrm{Fe}-\mathrm{Ni})}^{\mathrm{O}}\right]\left(K_{\mathrm{Al}} /[\% \mathrm{Al}]^{2}\right)^{1 / 3}\right\}
\end{aligned}
$$




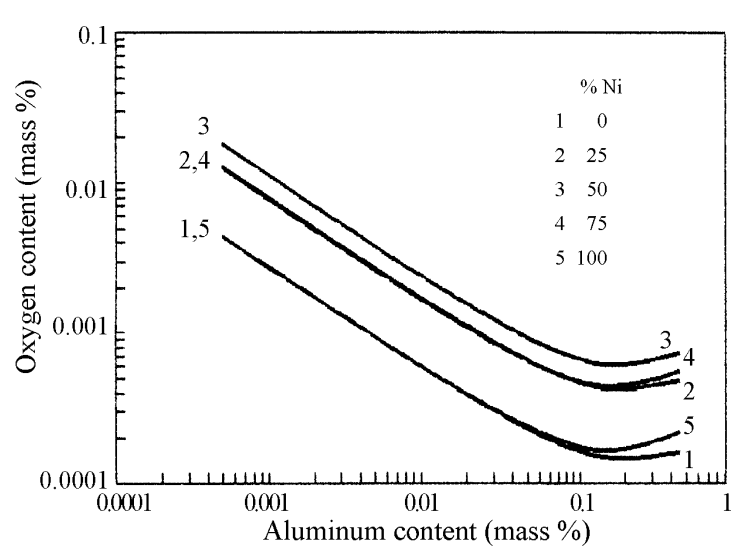

Fig. 2. Dependence of oxygen content in the Fe-Ni melts on the contents of $\mathrm{Al}$ and $\mathrm{Ni}$ at $1873 \mathrm{~K}$.

The dependence of the oxygen equilibrium concentration calculated by Eq. (9a) on the aluminum content in the $\mathrm{Fe}-\mathrm{Ni}$ melts at $1873 \mathrm{~K}$ is shown in Fig. 2. The interaction parameters $e_{i}^{j}$ used upon calculation for the melts with the different compositions (Table 1) were determined assuming ${ }^{1)}$ that

$$
\varepsilon_{i(\mathrm{Fe}-\mathrm{Ni})}^{j}=\varepsilon_{i(\mathrm{Fe})}^{j} X_{\mathrm{Fe}}+\varepsilon_{i(\mathrm{Ni})}^{j} X_{\mathrm{Ni}}
$$

As is seen from the data represented, the deoxidation ability of aluminum decreases initially with the increase in the nickel content to about $50 \%$ and, then, it rises. In pure nickel, the aluminum deoxidation ability is almost the same as that in pure iron. The oxygen solubility curves pass through the minimum whose position does not depend on the nickel content in the melt. The minimum oxygen concentrations are reached at the aluminum content equal to about $0.2 \%$; with the further addition of aluminum, the oxygen concentration increases.

\section{Experimental}

Deoxidation of iron-nickel melts with aluminum and silicon (separately and together) has been studied experimentally by using the $\mathrm{Fe}-40 \% \mathrm{Ni}$ melt as an example. The experiments have been carried out in an induction furnace fed by an $10 \mathrm{kV} \cdot \mathrm{A}$ HF generator. Carbonyl iron (99.99\%), electrolytic nickel $(99.99 \%)$, and primary aluminum $(99.99 \%)$ were used as a charge. The metal was melted in the $\mathrm{Ar}-\mathrm{H}_{2}$ atmosphere at $1873 \mathrm{~K}$ in alumina crucibles. Deoxidizing agents were introduced into the melt without breaking the furnace air-tightness; then this melt was held at a given temperature until equilibrium in the Ar atmosphere. Aluminum was introduced into the melt in the nickel capsules with the help of alumina rod. The temperature was measured by the $\mathrm{Pt}-6 \% \mathrm{Rh} / \mathrm{Pt}-30 \% \mathrm{Rh}$ thermocouple. Previous experiments showed the equilibrium to be attained for 20-25 min, which was confirmed by the constancy of oxygen concentration in metal at a given aluminum content. In the course of these experiments, the metal was sampled upon holding every five minutes. Upon subsequent experiments, when aluminum was added, metal was held at a given temperature for $40 \mathrm{~min}$ and then it was also sampled; samples were analyzed for nickel, aluminum, and silicon. The content of $\mathrm{Ni}, \mathrm{Al}$ and $\mathrm{Si}$ in samples was determined by ICP method. The oxygen concentration was determined by

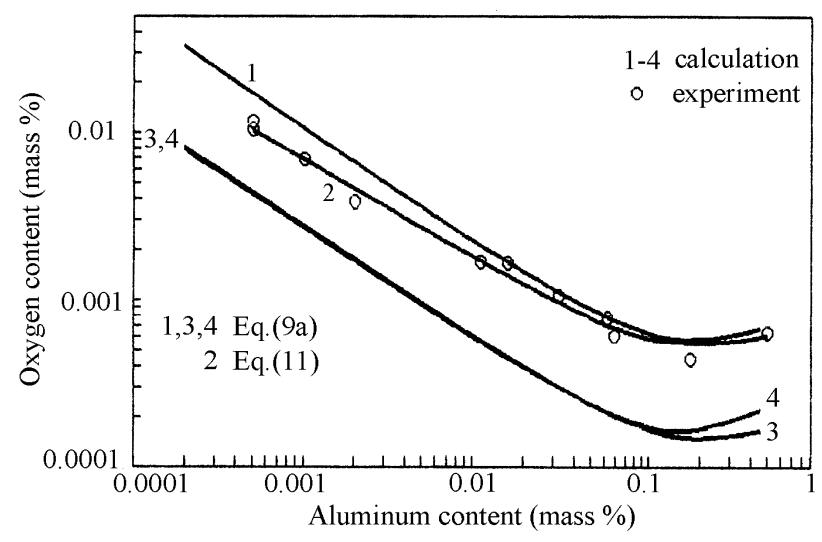

Fig. 3. Dependence of oxygen content in the $\mathrm{Fe}-40 \% \mathrm{Ni}$ melts $(1,2), \mathrm{Fe}(3)$, and $\mathrm{Ni}(4)$ on the content of $\mathrm{Al}$ at $1873 \mathrm{~K}$.

inert gas fusion-infrared absorptiometry.

\section{Results and Discussion}

\subsection{Deoxidation with Aluminum}

The experimental results on the deoxidation of $\mathrm{Fe}-$ $40 \% \mathrm{Ni}$ alloy with aluminum are shown in Fig. 3 as compared to the calculated lines for iron, nickel and the $\mathrm{Fe}-40 \% \mathrm{Ni}$ alloy. As is seen in this figure, the experimental results are in good agreement with the data calculated, which indicates the validity of the calculation method used. The dependence of the oxygen concentration on the aluminum content in the melt, which were calculated according to the experimental data, can be described by the following empirical equations:

$$
\log [\% \mathrm{O}]_{\mathrm{Al}}^{\exp }=-3.925+1.012[\% \mathrm{Al}]-0.587 \log [\% \mathrm{Al}]
$$

\subsection{Complex Deoxidation with Aluminum and Silicon}

In the case of complex deoxidation of metal melt with two and more deoxidizing agents, the activities of oxides formed upon deoxidation are less than unity if these oxides can form the solutions and chemical compounds with each other. Due to this fact, at the same contents of deoxidizers, the metal with the lower oxygen content can be produced. Upon complex deoxidation with aluminum and silicon, the former preferably reacts. The formation of solutions and chemical compounds between the oxides of silicon and aluminum promotes the participation of silicon in the deoxidation process.

Experimental data on the complex deoxidation of $\mathrm{Fe}-40 \% \mathrm{Ni}$ alloy with aluminum $(0.0003-0.28 \%)$ and silicon $(0.50-0.60 \%)$ at $1873 \mathrm{~K}$ are represented in Table 2. The experimental data indicated can be described by the following empirical equation:

$$
\log [\% \mathrm{O}]_{(\mathrm{Al}+\mathrm{Si})}=-4.125+2.197[\% \mathrm{Al}]-0.501 \log [\% \mathrm{Al}]
$$

The experimental data on the complex deoxidation of $\mathrm{Fe}-40 \% \mathrm{Ni}$ melt with aluminum and silicon and also the curve respectively calculated by Eq. (12) are shown in Fig. 4. The data represented indicate that, upon complex deoxidation with aluminum and silicon, the oxygen concentra- 
Table 2. Equilibrium oxygen concentrations in the case of complex deoxidation of $\mathrm{Fe}-40 \% \mathrm{Ni}$ alloy with $\mathrm{Al}$ and $\mathrm{Si}$.

\begin{tabular}{|c|c|c||c|c|c|}
\hline$[\mathrm{Si}], \%$ & {$[\mathrm{Al}], \%$} & {$[\mathrm{O}] \cdot 10^{4}, \%$} & {$[\mathrm{Si}], \%$} & {$[\mathrm{Al}], \%$} & {$[\mathrm{O}] \cdot 10^{4}, \%$} \\
\hline 0.51 & 0.0003 & 45.3 & 0.52 & 0.0080 & 7.5 \\
\hline 0.55 & 0.0005 & 29.1 & 0.59 & 0.0130 & 5.5 \\
\hline 0.50 & 0.0010 & 25.9 & 0.59 & 0.0170 & 7.5 \\
\hline 0.54 & 0.0020 & 14.2 & 0.60 & 0.0430 & 5.7 \\
\hline 0.53 & 0.0030 & 16.9 & 0.52 & 0.2800 & 5.8 \\
\hline
\end{tabular}

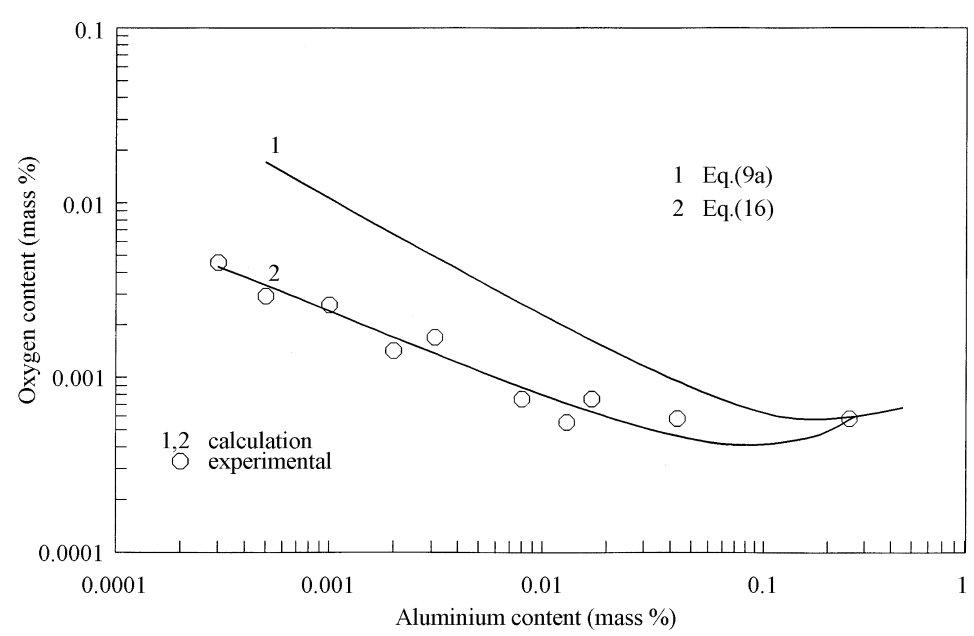

Fig. 4. Dependence of oxygen content in the $\mathrm{Fe}-40 \% \mathrm{Ni}$ melts on the contents of $\mathrm{Al}$ and $\mathrm{Si}(0.5-0.6 \%)$ at $1873 \mathrm{~K}$.

tions reached in the melt are lower than those after the deoxidation only with aluminum. However, when the aluminum content rises in the melt at the same silicon concentration, this difference decreases; at a certain aluminum concentration, its deoxidation power becomes equal to that of complex action of aluminum and silicon. This occurs due to an increase in the content of aluminum oxide in slag. When the slag is saturated with aluminum oxide $\left(a_{\mathrm{Al}_{2} \mathrm{O}_{3}}=1\right)$, silicon does not take part in the deoxidation. For the studied range of silicon contents $(0.50-0.60 \%)$, the slag is saturated with aluminum oxide at $0.217 \% \mathrm{Al}$.

\section{Conclusions}

Thermodynamic analysis and experimental data showed the deoxidizing ability of aluminum for iron-nickel melts to be lower than that for pure iron and nickel. As nickel content in the melt increases to about $50 \%$, the deoxidizing ability of aluminum decreases but then it rises. On one hand, this can be explained by an increase in the bond strengths of aluminum in melt with the nickel concentration and, on the other hand, by a decrease in the bond strengths of oxygen.

Complex deoxidation of the $\mathrm{Fe}-40 \%$ melt $\mathrm{Ni}$ aluminum and silicon has been experimentally studied. The formation of solutions and chemical compounds between oxides of aluminum and silicon promotes the participation of silicon in the deoxidation. Upon complex deoxidation, the lower oxygen concentrations are reached as compared to the deoxidation only with aluminum.

\section{Acknowledgments}

We thank the managing officers of Sumitomo Metal Industries Ltd. for their support in the research performance.

\section{REFERENCES}

1) V. Ya. Dashevskii, A. M. Katsnelson, N. N. Makarova, K. V. Grigorovitch and V. I. Kashin: ISIJ Int., 43 (2003), No. 10, 1487.

2) I. S. Kulikov: Deoxidation of Alloys, Metallurgija, Moscow, (1975), 504.

3) Steelmaking Data Soucebook, Gordon \& Breach Science Publ., New York, (1988), 325.

4) S. Dimitrov, A. Weyl and D. Janke: Steel Res., 66 (1995), No. 1, 3.

5) J.-D. Seo, S.-H. Kim and K.-R. Lee: Steel Res., 69 (1998), No. 2, 49.

6) F. Ishii and S. Ban-ya: Tetsu-to-Hagané, 81 (1995), 22.

7) S.-W. Cho and H. Suito: Steel Res., 66 (1995), No. 6, 237.

8) V. Ya. Dashevskii, A. M. Katsnelson, N. N. Makarova and V .I. Kashin: Metall, 1 (1997), 3.

9) M. G. Frohberg and M. Wang: Z. Metallkd., 81 (1990), 513.

10) T. Chiang and Y. A. Chang: Metall. Trans. B, 7B (1976), 453.

11) G. K. Sigworth, J. F. Elliott, G. Vaughn and G. H. Geiger: Met. Soc. CIM, Ann. V. (1977), 104.

12) I. S. Kulikov and A. M. Samarin: Izv. Acad. Sci. OTN, 10 (1954), 23. 